\title{
Author Correction: Sclerostin inhibits Wnt signaling through tandem interaction with two LRP6 ectodomains
}

Jinuk Kim, Wonhee Han, Taeyong Park, Eun Jin Kim, Injin Bang, Hyun Sik Lee, Yejin Jeong, Kyeonghwan Roh, Jeesoo Kim, Jong-Seo Kim (1), Chanhee Kang, Chaok Seok (1), Jin-Kwan Han \& Hee-Jung Choi (D)

Correction to: Nature Communications https://doi.org/10.1038/s41467-020-19155-4, published online 23 October 2020.

In this article the author name Yejin Jeong was incorrectly written as Yejing Jeong. The original article has been corrected.

Published online: 02 February 2022

\begin{abstract}
(c) Open Access This article is licensed under a Creative Commons Attribution 4.0 International License, which permits use, sharing, adaptation, distribution and reproduction in any medium or format, as long as you give appropriate credit to the original author(s) and the source, provide a link to the Creative Commons license, and indicate if changes were made. The images or other third party material in this article are included in the article's Creative Commons license, unless indicated otherwise in a credit line to the material. If material is not included in the article's Creative Commons license and your intended use is not permitted by statutory regulation or exceeds the permitted use, you will need to obtain permission directly from the copyright holder. To view a copy of this license, visit http://creativecommons.org/licenses/by/4.0/.
\end{abstract}

(C) The Author(s) 2022 